Article

\title{
Examining Roles of Tour Dure Producers for Social Capital and Innovativeness in Community-Based Tourism
}

\author{
Jaehun Joo ${ }^{1}$ (D) Jeong-Ja Choi ${ }^{2}$ and Namhyun Kim ${ }^{2, *(\mathbb{D}}$ \\ 1 Division of Management, Dongguk University-Gyeongju, Gyeongju 38066, Korea; givej@dongguk.ac.kr \\ 2 Department of Hotel, Tourism, and Foodservice Management, Dongguk University-Gyeongju, \\ Gyeongju 38066, Korea; jjchoi@dongguk.ac.kr \\ * Correspondence: nkim@dongguk.ac.kr
}

Received: 6 September 2019; Accepted: 24 September 2019; Published: 27 September 2019

\begin{abstract}
The Dure community is a traditional meeting and collaborative effort for solving tasks and issues in rural farming villages in Korea. Recently, the South Korean government has tried to revitalize Dure communities to develop tourism businesses in local provinces. Tour Dure projects aimed at revitalizing local communities and promoting sustainable economic development have been operating since 2013. Tour Dure producers, as change agents, play a critical role in the Tour Dure projects. The purpose of this study is to reveal the producers' roles in realizing community-based tourism (CBT). Using partial least squares structural equation modeling, this study analyzes the relationship between the producers' role and social capital in local communities and the subsequent impact on residents' innovativeness and life satisfaction. The results show that the producer's role is important in creating social capital, improving innovativeness, and, as a result, residents' life satisfaction. The present study suggests further implications for academics and policy makers focused on sustainable CBT.
\end{abstract}

Keywords: Tour Dure; community-based tourism; tourism business; social capital; innovativeness; life satisfaction

\section{Introduction}

Community-based tourism (CBT) was started as a form of alternative tourism aimed at reducing the negative effects of mass tourism [1], and it grew to become a way of sustainable tourism in many regions. CBT is characterized as being small scale in nature and involves interactions between visitors and host communities, especially in rural areas. Although the importance of CBT and sustainable tourism has been addressed, it has been difficult to identify best practices for realizing all the positive impacts of CBT in a tourism destination [2]. The concepts of both CBT and sustainable tourism emphasize the participation of residents, engagement of the local community, empowerment, capacity building, as well as resident solidarity with visitors [3,4]. However, in reality, these characteristics pose certain challenges to their development.

The Korean government and tourism scholars have tried to realize sustainable CBT in local communities in order to return the positive impact of tourism to local residents and revitalize the local economy. The "Tour Dure" (Tour Doore, Korean: 관광 두레) is a representative practice of CBT for sustainable tourism in Korea in order to make local residents engage and participate in the local tourism ecosystem. The Tour Dure is a community-based tourism business model that integrates the concept of sustainable CBT and the spirit of the Korean traditional community known as the Dure. Representing over 500 years of traditional culture, the Dure is a collective laboring activity which 
involves working together to complete projects in farming communities [5]. Since 2013, there have been 184 community-based tourism businesses initiated as Tour Dure projects in 47 regions in South Korea (see Figure A1). Tour Dure producers (hereafter, called PDs), who are sponsored by the Ministry of Culture, Sports, and Tourism, play an important role in implementing Tour Dure projects and facilitating innovation within Tour Dure communities. Tour Dure projects focus on the creation of both social and economic value as well as the improvement of quality of life in local communities. Therefore, Tour Dure is a social innovation project aimed at meeting social needs [6]. PDs play a critical role in driving improvements in residents' innovativeness and life satisfaction through the creation of social capital and capacity building. In that sense, the PD serves as a change agent who helps organizations transform by acting as a catalyst and assuming the responsibility for managing the change process [7].

Many studies argue that traditional local communities in Korean society were dismantled by rapid industrialization and urbanization [8]. The collapse of traditional communities in Korea has resulted in a lower level of social capital. According to the Organisation for Economic Co-operation and Development (OECD), community, as a social support network, is very important in the provision of emotional support, jobs, services, and other material opportunities because humans are social creatures [9]. In 2017, South Korea ranked at the bottom of the community index, one of the "Better Life" indices used to compare well-being across countries. The quality of community in South Korea, which is measured by the 'percentage of people who believe they can rely on their friends in case of need' was recorded as $75.9 \%$, the lowest of all 38 OECD countries. As a sense of community creates social capital $[10,11]$, in recent years, the Korean government has begun to sponsor and support a variety of initiatives aimed at the sharing economy, social economy, and urban regeneration for recovering and revitalizing communities as well as promoting local economic development. Industrialization, urbanization, and modernization efforts over the past 60 years in South Korea have reduced the level of traditional community spirit imbedded in Dure and Pumasi, another traditional form of collective labor in Korean agricultural society.

One of the promising objectives of the Tour Dure projects is to create social capital through the revitalization of local residents' sense of community. The PD contributes to creating social capital in the Tour Dure communities and improving residents' innovativeness and life satisfaction by providing educational opportunities based on his/her expertise and external experts. It is necessary to investigate the creation of social capital and the outcomes resulting from PDs' roles. Therefore, the purpose of the present study is to reveal the PDs' roles in realizing successful CBT in local areas. Specifically, the study aims to analyze the relationships among the PDs' role as a change agent for social innovation, social capital, innovativeness, and life satisfaction. The study results will assist policy makers and community activists in implement sustainable tourism projects at the local level.

\section{Theoretical Background}

\subsection{Social Capital and Structural Holes}

There have been many studies regarding social capital since the 1980s [12-14]. Social capital is defined as a set of resources derived from social relations among individuals and groups $[15,16]$. Social capital plays a significant role in regional development. Putnam [17] classified social capital into bridging social capital and bonding social capital. Bridging social capital is based on weak-tie relationships in which members liberally exchange simple information and perspectives without any emotional connections. Conversely, bonding social capital arises from strong-tie relationships such as those between family members and friends [18,19]. Nahapiet and Ghoshal [16] analyzed the role of social capital in creating intellectual capital by classifying social capital into structural, relational, and cognitive dimensions. The structural dimension of social capital represents network ties and indicates the level of connections and accessibility among participants and shows network configurations representing the level of cohesion. The relational dimension of social capital refers to the trust, beliefs, and sense of reciprocity that participants share. The cognitive dimension of social 
capital represents the common understanding of the core values and vision within the network. Social capital accrues when participants share values and a common vision within their trust-based relations. In addition, these three dimensions of social capital are interdependent and mutually connected [16].

Structural holes are the empty spaces in social structure [20]. In other words, a structural hole represents a weaker connection between groups in the social network. Structural holes provide opportunities to broker the flow of information between people and control benefits that represent bargaining power with people on the opposite side of group. Structural holes allow social networks to connect separated groups. Structural holes refer to weak ties rather than strong ties, which are related to bonding social capital through network closure [21]. According to Granovetter [22,23], people obtain jobs through weak ties rather than strong ties. Weak ties provide more new information and resources than strong ties. Bridging ties connecting structural holes provide new opportunities that are impossible in a closed network [20]. Therefore, structural holes create social capital based on the strength of weak ties.

The Tour Dure PD is a change agent who brokers connections between otherwise disconnected groups. The PD helps organizations transform by acting as a catalyst and assuming the responsibility of managing the change process. As shown in Figure 1, we propose that the PD serves as an important structural hole, bridging the separation between non-redundant contacts. A Tour Dure community consists of a local resident group and a government-led group. The resident group includes local people who are working in lodging, travel agencies, souvenirs, food and beverage outlets, and tour activities. The Korea Culture and Tourism Institute, Korea Tourism Organization, Ministry of Culture, Sports, and Tourism, and local governments all refer to government-led groups.

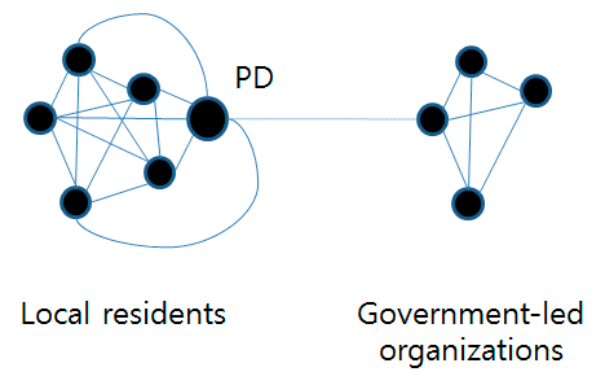

Figure 1. The Tour Dure producer (PD) as a structural hole in a Tour Dure network.

\subsection{Social Sustainability and the PD's Role in Tour Dure Projects in South Korea}

Tour Dure is a type of government-led project aimed at supporting and fostering tourism-related start-ups based on local communities in order to realize sustainable tourism. The principles and spirit of Tour Dure originated from traditional Dure in Korea. The Dure is defined as a type of collective laboring activity within farming communities of Korea. Local farmers in a village help each other with their farming needs, so that they can support each other in reducing the amount of work. The spirit of the traditional community has faded in recent years, and local tourism development usually depends on national companies and local governments. Therefore, the Korean government has tried to revitalize local communities and support sustainable CBT at the same time. In Tour Dure projects, there are many actors involved such as local residents, central and local governments, destination management organizations, and PDs, as shown in Table 1. Among them, we focus on the PDs' role in realizing sustainable CBT by facilitating social sustainability in the project.

Academic discussion on sustainability or sustainable tourism has been mainly focused on environmental concerns rather than social and economic dimensions [24-26]. Fortunately, interest in the social dimension of sustainability has also expanded in recent years [27]. Community sustainability involves social interaction between community members [27] and is associated with social capital and social cohesion, as suggested by Coleman [12]. For sustainable CBT, it is necessary to get local residents to participate and engage in tourism planning and development. The main challenges of 
sustainability projects, whether community or tourism development, are how to get residents to engage and empower them [24]. It is essential to make them motivated and confident through "social recognition" [28] and to consider individual resident's capabilities [29].

As shown in Table 1, the PD's role is multifaceted and involves finding residents who are interested in the tourism project and willing to work toward its continued success. As an expert in tourism or community development, the PD could enhance the residents' capabilities and support the establishment of Tour Dure enterprises. A more important role of the PD would be communicating with residents and connecting them with others inside or outside the project, thereby facilitating social capital and innovativeness. Without this role, residents would be more likely to quit the project and many conflicts that might occur during the project process would not be solved. From this aspect, we believe the PD's role is essential for a sustainable CBT project and realizing the social aspect of sustainability in a local community.

Table 1. Actors of the Tour Dure project and their roles.

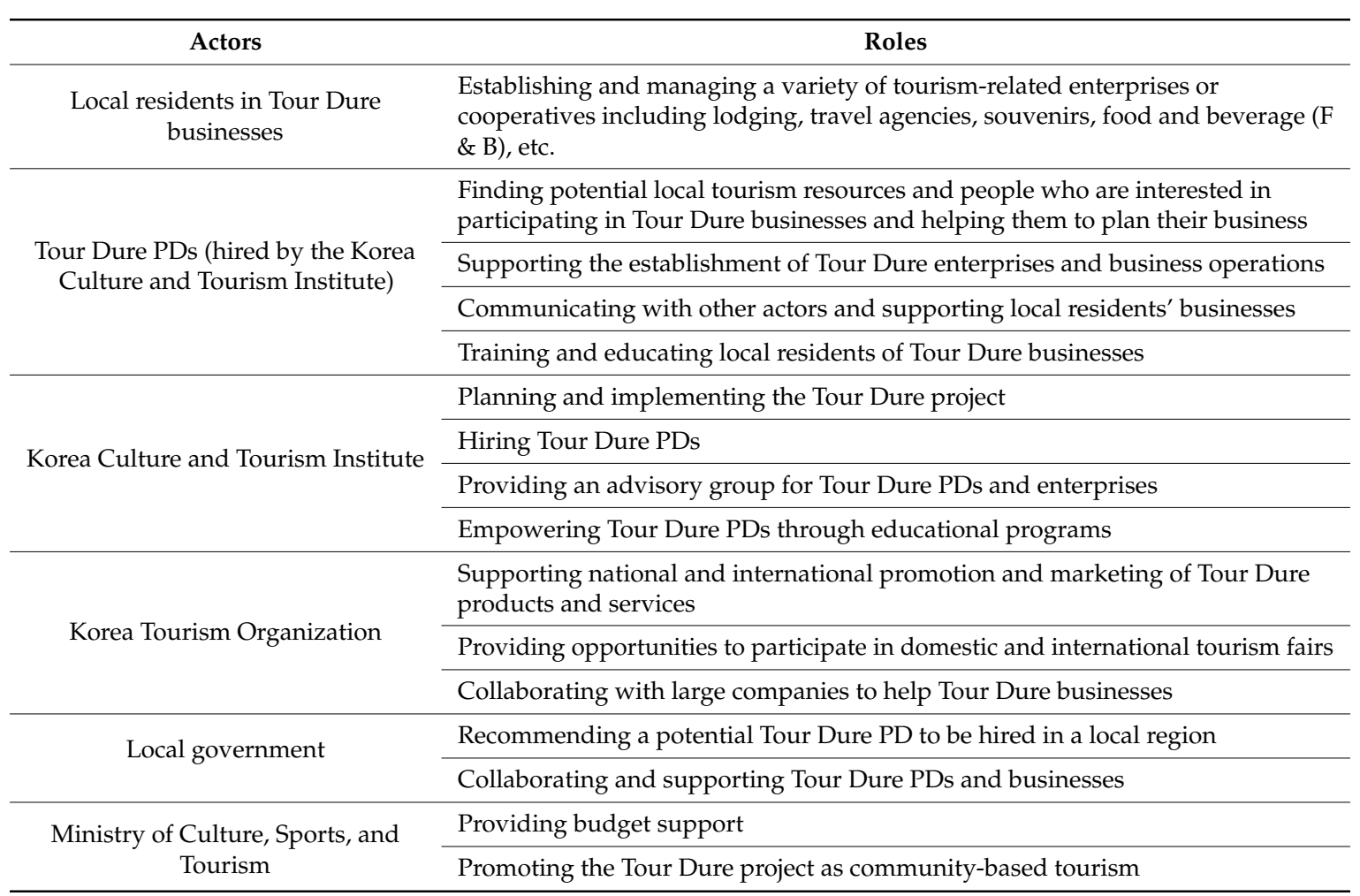

\section{Methodology}

\subsection{Hypothesis Development and Research Model}

As discussed above, community producers in Tour Dure projects contribute to creating social capital and cultivating local residents' innovativeness. Social capital, in turn, becomes an important resource for innovating local communities through the Tour Dure projects.

The PD of a Tour Dure network acts as a structural hole, brokering separate and non-redundant groups as shown in Figure 1. Thus, the PD creates bridging social capital in the Tour Dure community. According to Battilana and Casciaro [7], structural holes that refer to the low level of structural closure in a change agent's network facilitate the adoption of changes. Bonding social capital related to the high level of structural closure was not included in the research model shown in Figure 2. The PD's roles include persuading local residents and facilitating proactive participation by sharing the vision and values of the Tour Dure project. Thus, the PD creates the cognitive dimension of social capital. The PD's role can have a positive effect on residents who participate in Tour Dure projects through 
the creation of social capital in their community, and individual innovativeness can improve life satisfaction in the local community. Thus, the following research model is proposed.

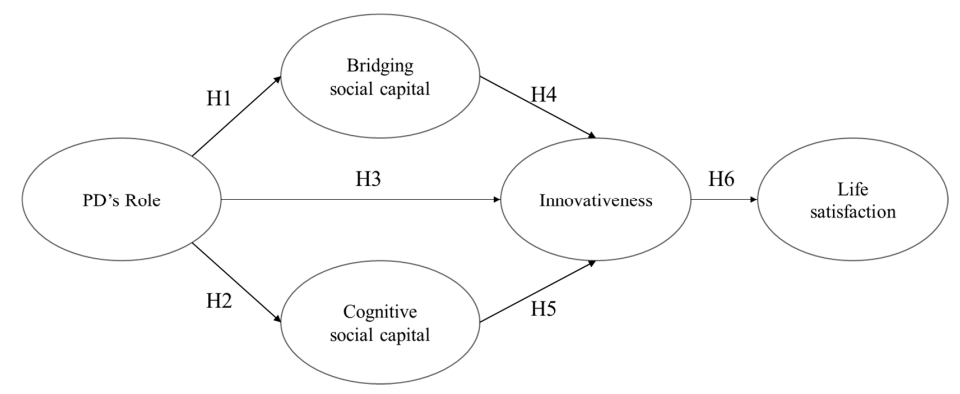

Figure 2. Research model.

\subsubsection{PDs' Role, Social Capital, and Innovativeness}

In implementing the Tour Dure initiative, the Korean government established the role of the $\mathrm{PD}$ as an intermediary agent for cooperation between government and local residents, and among residents [30]. Kim and Kim [31] emphasized the role of Tour Dure PDs in the relationship between the formation and performance of cooperative governance for Tour Dure. The study revealed that the Tour Dure PD, as an intermediary agent, plays an important role in the increased influence of reliability and policy support on the operational efficiency of the project. The PD serves to reinforce the capacity of local residents and facilitate network activities and the exchange of information among stakeholders [31]. This study tries to identify the direct role of the PD on building social capital in Tour Dure communities and increasing the innovativeness of participating local residents.

There are a few studies regarding the relationship between change agents and social capital. Frank et al. [32] studied the relationships between change agents, social capital, and the diffusion of innovation in educational communities. Change agents, in the form of teachers or educational experts, have a positive effect on novices' adoption of educational innovation by drawing on social capital and providing information and assistance. Community foundations also play a leadership role in building social capital [33]. Kim and Ryu [34] argued that change agents focused on human resources (HR) play a moderating role in the relationship between the social capital of HR departments and HR effectiveness. According to Monge et al.'s [35] study regarding change agents' role in local farmers' adoption of innovation, change agents promote and foster the adoption of innovation through technical assistance and knowledge transfer to local farmers. Accordingly, the following hypotheses are proposed:

Hypothesis 1 (H1). The producers' role in Tour Dure has a positive influence on bridging social capital in Tour Dure communities.

Hypothesis 2 (H2). The producers' role in Tour Dure has a positive influence on cognitive social capital in Tour Dure communities.

Hypothesis 3 (H3). The producers' role in Tour Dure has a positive influence on participants' perceived innovativeness.

Casanueva and Gallego [36] showed that the relational and resource dimensions of social capital have a significantly positive impact on individual innovativeness among university researchers. Schienstock and Hämäläinen [37] emphasized that social capital affects the innovation process, and this effect can connect social capital with innovativeness. On the contrary, Chang et al. [38] showed an insignificant relationship between social capital and organizational innovativeness among employees 
in the manufacturing industry. Ahuja [39] stressed, at a firm level, that structural holes among firms have a negative influence on innovation performance.

Social capital is just one element of an actor's innovative capability [40]. In the hospitality industry, Martínez-Pérez et al. [41] asserted that the social capital of workers positively affected firms' level of innovation. García-Villaverde et al. [42] showed that cognitive social capital positively affected radical innovation in hospitality firms, whereas structural social capital negatively influenced it. That means, weak ties or structural holes could be better for radical innovation than strong ties. Kim and Shim [43] found that cognitive social capital and inter-firm network density among SMEs in a tourism cluster had a significant and positive impact on innovation through knowledge sharing [43]. Considering that Tour Dure businesses are characterized as small- to medium-sized businesses, cognitive social capital and broad networks with others outside their business would likely influence their innovativeness. Accordingly, the following hypotheses are proposed:

Hypothesis 4 (H4). Bridging social capital has a positive influence on participants' perceived innovativeness.

Hypothesis 5 (H5). Cognitive social capital has a positive influence on participants' perceived innovativeness.

\subsubsection{Innovativeness and Satisfaction with Life}

The relationship between individual innovativeness and life satisfaction is complex [44]. Huhtala and Parzefall [45] suggest that innovativeness and well-being have a bi-directional relationship in a work domain. Honkaniemi, Lehtonen, and Hasu [46] also found that high innovativeness is positively related with well-being and vice versa.

In the individual domain, however, innovativeness encourages one to create opportunities to lead a more valuable and challenging life, consequently leading to greater satisfaction with life and successful aging [47]. Nimrod [48] and Ali [44] showed that innovative individuals were more likely to perceive satisfaction with their lives. In the field of education, it has been found that individual innovativeness has a significant positive relationship with psychological well-being among students who are trained as counselors in Turkey [49]. Therefore, if the community members who participate in Tour Dure projects perceive enhanced innovativeness, they will be more likely to feel satisfied with their individual lives. Accordingly, the sixth hypothesis is proposed:

Hypothesis 6 (H6). Perceived innovativeness has a positive influence on perceived life satisfaction.

\subsection{Measurement}

The operational definition of each construct of the research model is shown in Table 2.

Table 2. Operational definitions.

\begin{tabular}{cl}
\hline Construct & \multicolumn{1}{c}{ Definition } \\
\hline $\begin{array}{c}\text { Community producers' } \\
\text { role in Tour Dure }\end{array}$ & $\begin{array}{l}\text { The degree to which a local resident who participates in a Tour Dure project perceives that the } \\
\text { producer's role in its community has been successful (e.g., supporting the establishment and } \\
\text { incubation of sustainable tourism start-ups, investigating demand for tourism businesses, and } \\
\text { consulting on business plans) }\end{array}$ \\
\hline Bridging social capital & $\begin{array}{l}\text { The degree to which a local resident who participates in a Tour Dure project has open and inclusive } \\
\text { relations with other people outside of the Tour Dure community }\end{array}$ \\
\hline Cognitive social capital & $\begin{array}{l}\text { The degree to which a local resident who participates in a Tour Dure project understands the vision } \\
\text { and goals and shares them with other members }\end{array}$ \\
\hline $\begin{array}{c}\text { Perceived } \\
\text { innovativeness }\end{array}$ & $\begin{array}{l}\text { The degree to which a local resident who participates in a Tour Dure project perceives his or her } \\
\text { innovativeness as a result of the project and the PDs' role in local community }\end{array}$ \\
\hline Life satisfaction & $\begin{array}{l}\text { The degree to which a local resident who participates in a Tour Dure project perceives improvement } \\
\text { in his (or her) life satisfaction as a result of the project }\end{array}$ \\
\hline
\end{tabular}


We developed a questionnaire after conducting an extensive literature review and considering the uniqueness of Tour Dure. There are 39 PDs in total. The PDs' roles have not previously been fully investigated. As a result, we interviewed 4 PDs in order to identify their roles in the Tour Dure communities. For developing the PD role, we referred to results of interviews with PDs and Kim and Kim's [31] study and modified for the purpose of this study. Kim and Kim [31] identified the roles of Tour Dure PDs and their challenges in facilitating the projects in local regions. Social capital was classified into two dimensions: bridging and cognitive social capital, adapting measurements from Nahapiet and Ghoshal [16] and Williams [50]. Innovativeness consists of four items adapted from Agarwal and Prasad [51] and Tan and Sie [52]. Five items were used to measure individual life satisfaction, using questions adapted from Fornell et al. [53] and modified for our study. Table 3 shows the measurement items for the questionnaire.

Table 3. Measurement items.

\begin{tabular}{|c|c|c|c|}
\hline Construct & Code & Items & Reference \\
\hline \multirow{11}{*}{$\begin{array}{l}\text { Tour Dure PDs' role } \\
\text { (PDR) }\end{array}$} & PDR1 & $\begin{array}{l}\text { I think PDs play an important role in business } \\
\text { planning. }\end{array}$ & \multirow{11}{*}{$\begin{array}{l}\text { Self-developed, } \\
\text { Kim and Kim [31] }\end{array}$} \\
\hline & PDR2 & $\begin{array}{l}\text { I think PDs play an important role in organizing } \\
\text { residents to start tourism businesses and } \\
\text { establishing Tour Dure enterprises. }\end{array}$ & \\
\hline & PDR3 & $\begin{array}{l}\text { I think PDs contribute greatly to running Tour } \\
\text { Dure businesses. }\end{array}$ & \\
\hline & PDR4 & $\begin{array}{l}\text { I think PDs play an important role in successfully } \\
\text { driving tourism businesses. }\end{array}$ & \\
\hline & PDR5 & $\begin{array}{l}\text { I think PDs play an important role in turning Tour } \\
\text { Dure businesses into future-oriented businesses. }\end{array}$ & \\
\hline & PDR6 & $\begin{array}{l}\text { I think PDs play an important role in the positive } \\
\text { change in the participants of Tour Dure } \\
\text { businesses. }\end{array}$ & \\
\hline & PDR7 & $\begin{array}{l}\text { I think PDs are making a lot of efforts to support } \\
\text { Tour Dure businesses. }\end{array}$ & \\
\hline & PDR8 & $\begin{array}{l}\text { I think PDs have a lot of affection and attachment } \\
\text { to Tour Dure businesses. }\end{array}$ & \\
\hline & PDR9 & $\begin{array}{l}\text { I think PDs are doing something that helps } \\
\text { community development. }\end{array}$ & \\
\hline & PDR10 & $\begin{array}{l}\text { I think PDs play an important role in forming a } \\
\text { cooperative relationship with tourism } \\
\text { stakeholders (tourism authorities, local } \\
\text { governments, research institutes, etc.) for the } \\
\text { success of Tour Dure businesses. }\end{array}$ & \\
\hline & PDR11 & $\begin{array}{l}\text { I think that PDs act as changemakers that drive } \\
\text { change (in the community) through Tour Dure } \\
\text { businesses. }\end{array}$ & \\
\hline \multirow{4}{*}{$\begin{array}{l}\text { Bridging social } \\
\text { capital (BSC) }\end{array}$} & BSC1 & $\begin{array}{l}\text { I am interested in what happens outside the Tour } \\
\text { Dure enterprise. }\end{array}$ & \multirow{4}{*}{$\begin{array}{l}\text { Putnam [17]; } \\
\text { Williams [50] }\end{array}$} \\
\hline & BSC2 & $\begin{array}{l}\text { I accept opinions from outside the Tour Dure } \\
\text { enterprise positively. }\end{array}$ & \\
\hline & $\mathrm{BSC} 3$ & $\begin{array}{l}\text { I accept ideas from outside the Tour Dure } \\
\text { enterprise positively. }\end{array}$ & \\
\hline & BSC4 & $\begin{array}{l}\text { I feel positive about the participation of others in } \\
\text { the Tour Dure business I am engaged in. }\end{array}$ & \\
\hline
\end{tabular}


Table 3. Cont.

\begin{tabular}{|c|c|c|c|}
\hline Construct & Code & Items & Reference \\
\hline \multirow{3}{*}{$\begin{array}{l}\text { Cognitive social } \\
\text { capital (CSC) }\end{array}$} & CSC1 & $\begin{array}{l}\text { I am well aware of the goal of our Tour Dure } \\
\text { business. }\end{array}$ & \multirow{3}{*}{$\begin{array}{c}\text { Hazleton and } \\
\text { Kennan [54]; } \\
\text { Nahapiet and } \\
\text { Ghoshal [16]; Tsai } \\
\text { and Ghoshal [55] }\end{array}$} \\
\hline & $\mathrm{CSC} 2$ & $\begin{array}{l}\text { I am well aware of the vision of our Tour Dure } \\
\text { business. }\end{array}$ & \\
\hline & $\mathrm{CSC} 3$ & $\begin{array}{l}\text { I share a common vision with members of Tour } \\
\text { Dure business. }\end{array}$ & \\
\hline \multirow{4}{*}{ Innovativeness (INN) } & INN1 & $\begin{array}{l}\text { After participating in the Tour Dure business, I } \\
\text { gradually became active in suggesting new ideas. }\end{array}$ & \multirow{4}{*}{$\begin{array}{c}\text { Agarwal and } \\
\text { Prasad [51]; Tan } \\
\text { and Sie [52]; } \\
\text { Eklinder-Frick et al. } \\
\text { [56]; Ikiz and Asici } \\
\text { [49] }\end{array}$} \\
\hline & INN2 & $\begin{array}{l}\text { After participating in the Tour Dure business, I } \\
\text { am gradually developing a tendency to challenge } \\
\text { new things. }\end{array}$ & \\
\hline & INN3 & $\begin{array}{l}\text { Compared to before participating in the Tour } \\
\text { Dure business, I accept new things more readily. }\end{array}$ & \\
\hline & INN4 & $\begin{array}{l}\text { Compared to before participating in the tourism } \\
\text { business, I tend to be more innovative. }\end{array}$ & \\
\hline \multirow{5}{*}{$\begin{array}{l}\text { Life satisfaction } \\
\text { (LSA) }\end{array}$} & LSA1 & $\begin{array}{l}\text { Compared to the initial stage, I am more positive } \\
\text { about Tour Dure. }\end{array}$ & \multirow{5}{*}{$\begin{array}{l}\text { Fornell et al. [53]; } \\
\text { Hsu [57] }\end{array}$} \\
\hline & LSA2 & $\begin{array}{l}\text { Compared to the initial stage, my satisfaction } \\
\text { with the benefits provided by the Tour Dure has } \\
\text { improved. }\end{array}$ & \\
\hline & LSA3 & $\begin{array}{l}\text { Compared to the initial stage, my satisfaction } \\
\text { with the overall Tour Dure has improved. }\end{array}$ & \\
\hline & LSA4 & $\begin{array}{l}\text { My satisfaction with the community in which I } \\
\text { live has improved through Tour Dure. }\end{array}$ & \\
\hline & LSA5 & $\begin{array}{l}\text { Overall, my satisfaction with life has improved } \\
\text { through Tour Dure. }\end{array}$ & \\
\hline
\end{tabular}

\subsection{Data Collection and Analysis}

Data were collected from local residents participating in the Tour Dure project in 2018 through both online and on-site surveys. The surveys were conducted from 4 June 2018 to 10 December 2018. The total population was comprised of 1322 residents, participating in a total of 184 Tour Dure businesses. We asked the Tour Dure Center, the government organization in charge of operating Tour Dure project in Korea, to help collect data from participants and send the link to the online survey to the participants. For the on-site survey, we visited the Annual Tour Dure Fair held in Andong City, Korea on 10 September 2018, and five trained survey interviewers distributed a self-administered questionnaire to participants who had not previously answered the online survey. A total of 222 valid samples were collected for analysis. The respondents represent a total of 71 Tour Dure businesses that have been operating since 2013.

This study applied partial least squares structural equation modeling (PLS-SEM) to test the research hypotheses (Figure 2). PLS-SEM, variance-based SEM, is useful for developing theory and analyzing a structural model with small sample size (less than 250) [58]. A PLS path model is described by a measurement model (outer model) and a structural model (inner model). The measurement model is evaluated with criteria such as loadings coefficients between indictor variables and a construct, Cronbach's alpha, composite reliability, and average variance extracted (AVE) for checking reliability and validity [59]. The structural model (inner model) in PLS is evaluated by criteria such as the $\mathrm{R}^{2}$ of endogenous latent variables, estimates for path coefficients (t-statistics), and the standardized root mean square residual (SRMR) [60]. SPSS Statistics (Version 23) and SmartPLS (Version 3.2.7, Ringle et al. [59]) were utilized to analyze the data. SmartPLS supports variance-based SEM and also confirmatory factor analysis (CFA), whereas Amos is covariance-based SEM. SmartPLS supports both 
structural (inner) model and measurement (outer) model which provides all statistics related to CFA such as loadings coefficients between indictor variables and a construct, Cronbach's alpha, composite reliability, and average variance extracted (AVE) for checking reliability and validity [59].

\section{Results}

\subsection{Characteristics of Respondents}

Table 4 shows the demographic characteristics of the respondents. The percentage of female respondents is $60.4 \%$. The percentage of respondents aged 40 to 60 years old is $61.2 \%$, and $46.9 \%$ of the respondents have been participating in Tour Dure businesses for more than two years.

Table 4. Demographic characteristics.

\begin{tabular}{cccc}
\hline Variable & Categories & Frequency & Percentage \\
\hline \multirow{2}{*}{ Gender } & Male & 88 & 39.6 \\
& Female & 134 & 60.4 \\
\hline \multirow{4}{*}{ Age } & $20-29$ & 19 & 8.6 \\
& $30-39$ & 28 & 12.6 \\
& $40-49$ & 54 & 24.3 \\
& $50-59$ & 82 & 36.9 \\
Experience & Over 60 & 39 & 17.6 \\
& Under 1 year & 75 & 33.8 \\
& 1-2 years & 43 & 19.4 \\
& 2-3 years & 44 & 19.8 \\
& 3-4 years & 41 & 18.5 \\
& Over 4 years & 19 & 8.6 \\
\hline
\end{tabular}

\subsection{Reliability and Validity}

To avoid common method bias (CMB), the total variance of the unrotated first factor should be less than $50 \%$ according to the Harman single factor test, which includes all items from all constructs into exploratory factor analysis [61]. The first factor explains $23.76 \%$ of the total variance. Thus, the possibility of CMB is too low [61]. A full collinearity test is also used to investigate CMB. According to Kock [62], a model containing $\mathrm{CMB}$ has a latent variable with a variance inflation factor (VIF) greater than 3.3. All VIFs of the research model range from 1.000 to 1.760 . Thus, the research model does not present CMB.

Table 5 shows path loadings connecting each construct to the indicator variables, Cronbach's alpha, composite reliability, and average variance extracted (AVE). The indicator reliability of the measurement model is acceptable because the outer model loadings for all constructs are greater than 0.7 [63,64]. All Cronbach's alphas exceed the 0.7 threshold for internal consistency $[65,66]$. Composite reliabilities (CRs) for all constructs also exceed a cutoff value of 0.7 [64] (p. 269). Thus, the reliability and convergent validity of the model are satisfactory $[67,68]$.

Table 6 shows the inter-construct correlations and the square root of AVE for each construct. The bold values in diagonal cells indicate the square root of AVE. The square root of AVE for each construct is higher than its correlations with other constructs. According to the Fornell and Larcker criterion, discriminant validity is satisfactory [67].

The heterotrait-monotrait ratio (HTMT) was suggested as a criterion of discriminant validity by Henseler et al. [69]. Discriminant validity is satisfactory for a given pair of constructs if the HTMT value is below 0.90 [68]. Gold et al. [70] and Teo et al. [71] also recommended the 0.90 threshold, though Kline [72] uses the more stringent cutoff of 0.85. All values in Table 7 are less than 0.755 . Thus, the discriminant validity is satisfied. 
Table 5. Internal consistency and convergent validity.

\begin{tabular}{|c|c|c|c|c|c|}
\hline Variable & Item & $\begin{array}{l}\text { Indicator } \\
\text { Loading }\end{array}$ & $\begin{array}{c}\text { Cronbach's } \\
\text { Alpha }\end{array}$ & $\begin{array}{l}\text { Composite } \\
\text { Reliability }\end{array}$ & $\begin{array}{l}\text { Average Variance } \\
\text { Extracted (AVE) }\end{array}$ \\
\hline PD's role (PDR) & $\begin{array}{l}\text { PDR1 } \\
\text { PDR2 } \\
\text { PDR3 } \\
\text { PDR4 } \\
\text { PDR5 } \\
\text { PDR6 } \\
\text { PDR7 } \\
\text { PDR8 } \\
\text { PDR9 } \\
\text { PDR10 } \\
\text { PDR11 }\end{array}$ & $\begin{array}{l}0.776 \\
0.823 \\
0.864 \\
0.886 \\
0.890 \\
0.887 \\
0.890 \\
0.866 \\
0.850 \\
0.835 \\
0.898\end{array}$ & 0.965 & 0.969 & 0.742 \\
\hline $\begin{array}{l}\text { Bridging social } \\
\text { capital (BSC) }\end{array}$ & $\begin{array}{l}\text { BSC1 } \\
\text { BSC2 } \\
\text { BSC3 } \\
\text { BSC4 }\end{array}$ & $\begin{array}{l}0.835 \\
0.872 \\
0.850 \\
0.767\end{array}$ & 0.851 & 0.900 & 0.692 \\
\hline $\begin{array}{l}\text { Cognitive social } \\
\text { capital (CSC) }\end{array}$ & $\begin{array}{l}\text { CSC1 } \\
\text { CSC2 } \\
\text { CSC3 }\end{array}$ & $\begin{array}{l}0.903 \\
0.944 \\
0.893\end{array}$ & 0.901 & 0.938 & 0.834 \\
\hline $\begin{array}{l}\text { Innovativeness } \\
\text { (INN) }\end{array}$ & $\begin{array}{l}\text { INN1 } \\
\text { INN2 } \\
\text { INN3 } \\
\text { INN4 }\end{array}$ & $\begin{array}{l}0.882 \\
0.923 \\
0.899 \\
0.918\end{array}$ & 0.927 & 0.948 & 0.820 \\
\hline $\begin{array}{l}\text { Life satisfaction } \\
\text { (LSA) }\end{array}$ & $\begin{array}{l}\text { LSA1 } \\
\text { LSA2 } \\
\text { LSA3 } \\
\text { LSA4 } \\
\text { LSA5 }\end{array}$ & $\begin{array}{l}0.894 \\
0.870 \\
0.919 \\
0.900 \\
0.898\end{array}$ & 0.939 & 0.953 & 0.803 \\
\hline
\end{tabular}

Table 6. Discriminant validity: the Fornell-Larcker criterion.

\begin{tabular}{cccccc}
\hline Construct & PDR & BSC & CSC & INN & LSA \\
\hline PDR & $\mathbf{0 . 8 6 1}$ * & & & \\
BSC & 0.436 & $\mathbf{0 . 8 3 2}$ & & & \\
CSC & 0.502 & 0.600 & $\mathbf{0 . 9 1 3}$ & & \\
INN & 0.567 & 0.502 & 0.606 & $\mathbf{0 . 9 0 6}$ & \\
LSA & 0.567 & 0.493 & 0.545 & 0.545 & $\mathbf{0 . 8 9 6}$ \\
\hline \multicolumn{7}{c}{ * the square root of AVE. }
\end{tabular}

Table 7. Discriminant validity: the Heterotrait-Monotrait Ratio (HTMT).

\begin{tabular}{ccccc}
\hline Construct & PDR & BSC & CSC & INN \\
\hline BSC & 0.479 & & & \\
CSC & 0.531 & 0.685 & & \\
INN & 0.596 & 0.564 & 0.658 & \\
LSA & 0.591 & 0.549 & 0.583 & 0.755 \\
\hline
\end{tabular}

In general, when using PLS, the standardized root mean square residual (SRMR) is used as a measure of the approximate fit of the structural model [68]. The structural model has good fit because the SRMR value of 0.053 is below the cutoff of 0.08 [73]. 


\subsection{Hypothesis Test}

Path analysis using SmartPLS was used to test the six hypotheses. As shown in Table 8, all hypotheses except $\mathrm{H} 4$ were supported. H1, H2, H3, H5, and H6 were supported at a significance level of 0.001 .

Table 8. Path coefficients and results of hypothesis testing.

\begin{tabular}{|c|c|c|c|c|c|c|}
\hline Hypothesis & Path & Path Coefficient & SD & T Statistics & $p$ & Result \\
\hline H1 & $\mathrm{PDR} \rightarrow \mathrm{BSC}$ & 0.436 & 0.064 & 6.860 & $0.000(* * *)$ & Supported \\
\hline $\mathrm{H} 2$ & $\mathrm{PDR} \rightarrow \mathrm{CSC}$ & 0.502 & 0.070 & 7.129 & $0.000\left(^{* * *}\right)$ & Supported \\
\hline H3 & $\mathrm{PDR} \rightarrow \mathrm{CSC}$ & 0.325 & 0.074 & 4.386 & $0.000(* * *)$ & Supported \\
\hline $\mathrm{H} 4$ & $\mathrm{BSC} \rightarrow \mathrm{INN}$ & 0.147 & 0.080 & 1.831 & 0.067 & Not Supported \\
\hline H5 & $\mathrm{CSC} \rightarrow \mathrm{INN}$ & 0.355 & 0.085 & 4.195 & $0.000\left(^{* * *}\right)$ & Supported \\
\hline H6 & $\mathrm{INN} \rightarrow \mathrm{LSA}$ & 0.711 & 0.036 & 19.515 & $0.000\left(^{* * *}\right)$ & Supported \\
\hline
\end{tabular}

Figure 3 shows the measurement model representing the relationships between latent variables and their indicators with path coefficients and R-squared. All outer loadings of the measurement model are greater than the 0.7 cutoff value.

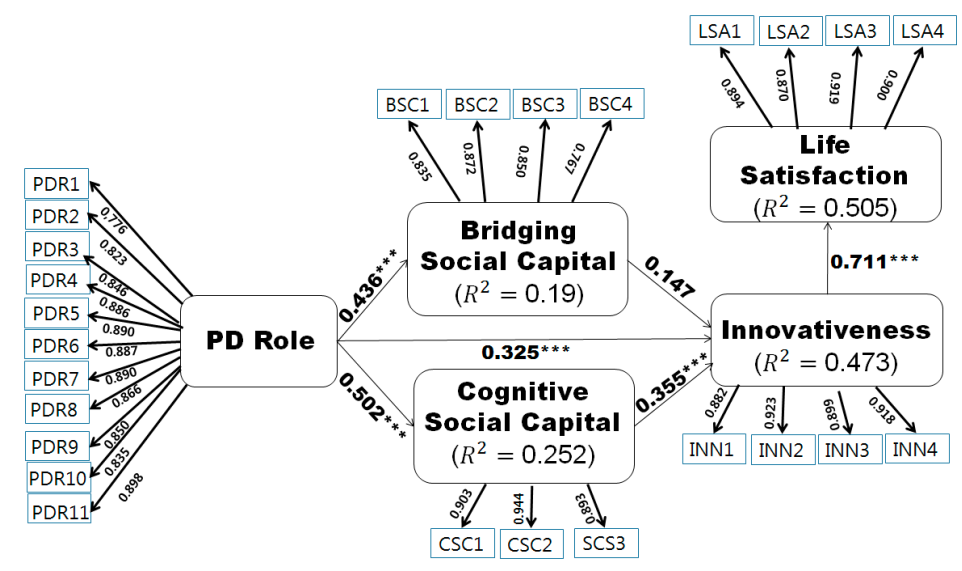

Figure 3. Analysis results of the measurements and structural model.

R-squared, known as the coefficient of determination, is measured by the variance explained through the model [68]. Chin [60] classified the levels of explanatory power into "substantial", "moderate", and "weak", with cutoff thresholds of $0.67,0.33$, and 0.19 , respectively $[60,68]$ (p. 323). Table 9 shows the R-squared, $t$-value, and $p$-value. All R-squared values are significant and exceed the 0.19 cutoff value. In particular, local residents' innovativeness explains $51 \%$ of the variance in life satisfaction as an endogenous variable.

Table 9. R-squared.

\begin{tabular}{cccc}
\hline Variable & R-Squared & $\boldsymbol{t}$-Value & $\boldsymbol{p}$-Value \\
\hline BSC & 0.190 & 3.397 & 0.000 \\
CSC & 0.252 & 3.578 & 0.000 \\
INN & 0.473 & 10.102 & 0.000 \\
LSA & 0.505 & 9.806 & 0.000 \\
\hline
\end{tabular}

\section{Discussion}

The present study proposed a new research model to examine the relationships between the PD's role as a change agent, social capital, local residents' innovativeness, and life satisfaction in Tour Dure 
communities. Six hypotheses were tested by using data collected from local residents participating in Tour Dure businesses.

The PD's role in Tour Dure projects has a positive influence on bridging and cognitive social capitals and innovativeness at a significance level of 0.001 . The more positively local residents view the PD's role in the community, the higher their perception of both bridging and cognitive social capital. This result supports previous studies such as Frank et al. [32] and Monge et al. [35]. The cognitive dimension of social capital has a positive influence on residents' innovativeness at a significance level of 0.001 , whereas bridging social capital has no significant effect on their innovativeness. Contrary to Chang et al.'s [38] study, the results showed that the better local residents understand and share the vision and objective of the Tour Dure business, the more their innovativeness is enhanced. The cognitive dimension of social capital, rather than bridging social capital, drives innovative change in local residents. These results are consistent with previous studies by Casanueva and Gallego [36], Schienstock and Hämäläinen [37], Martínez-Pérez et al. [41], and Kim and Shim [43]. Local residents' innovativeness has a positive influence on his (or her) life satisfaction at a significance level of 0.001 . The greater the improvement in innovativeness as a result of the Tour Dure business, the higher the perception of life satisfaction. This is consistent with the results of Nimrod [48] and Ali's [44] study. Thus, it is important for PDs of Tour Dure communities to enhance local residents' innovativeness, either directly or through the creation of the cognitive dimension of social capital, because their innovativeness is associated with their life satisfaction.

\subsection{Theoretical Implications}

The results propose some implications for academics. This study contributes to sustainable CBT research by considering the perspective of a change agent's role and social capital and by extending the analysis to participants' life satisfaction in a CBT model. No previous study currently exists in which the focus is on the concept of the third party as a change agent, such as PDs in a sustainable CBT model. From this point of view, the Tour Dure is one of the promising community revitalization initiatives, and our research model of Tour Dure is a unique and effective model aimed at community revitalization and sustainable tourism. The PDs play a critical role in the Tour Dure as a change agent. Our research model can be a guideline for identifying the relationships among the change agent's role, social capital, local residents' innovativeness, and life satisfaction. In addition, it can be applied to various research areas dealing with social capital and community actualization through the use of change agents.

The ultimate purpose of community revitalization is to improve local residents' life satisfaction. As stated by Dangi [74], various theoretical lenses have been applied to analyze interactions between tourists and residents. Nevertheless, no research in sustainable CBT to date has attempted to take the perspective of a change agent and social capital and to extend the analysis to residents' life satisfaction. Although there have been a few studies regarding the relationships between the change agent's role and social capital or social capital and innovation [32,35], our research model integrated a complex relationship connecting the contributions of the PD as a change agent to local residents' life satisfaction. As a change agent of the Tour Dure, the PD plays a significant role in creating both bridging and cognitive social capital. However, the cognitive dimension of social capital is more important in enhancing local residents' innovativeness than the bridging dimension of social capital. Although extant studies had already provided positive evidence of the relationship between social capital and life satisfaction [75-77], there had been no study identifying a mediating role of individual or organizational innovativeness between social capital and life satisfaction. The primary finding of this research asserts that the cognitive dimension of social capital plays a significant role in individuals' innovativeness, thereby increasing the level of their life satisfaction. 


\subsection{Practical Implications}

Findings of the research also suggest some implications for practitioners and policy makers who are aiming to practice sustainable CBT in local communities. The present study firstly analyzed the PDs' role in the Tour Dure projects using quantitative data, and the significance of the PDs' role in the realization of the Tour Dure projects was verified. The Tour Dure initiative in South Korea has been successful in terms of social capital and local residents' life satisfaction. This result provides evidence of a successful model of CBT for sustainability not only in Korea but also globally. The main challenges of CBT implementation are participation and engagement on the part of local residents and capacity building for them in CBT projects. At the heart of the Tour Dure initiative is the PD's important role in ensuring that local residents get involved and keep working on the projects.

The PDs contribute to the success of the Tour Dure projects. They serve as an important source of human capital in local communities as well as creating social capital. It is necessary to continue to reinforce PDs' cultivation and assistance in revitalizing local communities and improving local residents' life satisfaction through the creation of social capital and the increase in their level of innovativeness. Second, policy makers need to encourage the PDs' roles by brokering a joint group of residents and businesses and a government-led group. Policy makers need to build sustainable infrastructure so that PDs assuming a structural hole in the Tour Dure community network will be able to help local residents to share the vision and goals of Tour Dure. The structure of Tour Dure and change agents like the PD can be extended for other community revitalization such as urban regeneration and other social innovation projects in order to create social capital and enhance residents' life satisfaction. For example, the Ministry of Land, Infrastructure, and Transport (MOLIT) plans an investment of USD 46.5 billion in urban regeneration "New Deal" projects aimed at boosting the competitiveness of deteriorated urban areas and creating jobs through community revitalization [78]. The PDs' role in Tour Dure communities can be extended to serve as change agents of other areas including urban regeneration. Furthermore, this CBT model can be more widely applicable when implemented in rural communities in other countries, where they are generally less capable and therefore do not facilitate CBT.

\section{Conclusions}

This study has examined the roles of Tour Dure PD as a change agent for social innovation, social capital, innovativeness, and life satisfaction from the perspectives of residents participating in the Tour Dure Project. Specifically, the study aimed to examine the relationship among the PD's role, social capital, residents' innovativeness, and life satisfaction. Despite the fact that it is difficult to implement a CBT model in reality, this study suggests the importance of utilizing a change agent or facilitator. The PD contributes to leading change among local residents and their community, forming a cooperative relationship with various tourism stakeholders, creating social capital, and helping to increase local residents' innovativeness. The PD plays a lubricating role in the implementation of a sustainable CBT model. Recruiting a PD may not be a panacea, but the study confirms that it is an important way to realize CBT in local community. The Tour Dure initiative in Korea provides insights from two perspectives. First, the role of the PD, a change agent, is necessary for community development and sustainability. Second, CBT can contribute to local residents' life satisfaction by offering them the opportunity to participate in community-based tourism businesses.

Therefore, the novelty of this study is to provide a new research model examining relationships among the Tour Dure PD as a change agent, social capital, innovativeness, and life satisfaction. The present study confirmed that PDs play a critical role in building social capital and raising residents' innovativeness, and that PDs ultimately contribute to residents' life satisfaction in Tour Dure communities. The research model can be applied to other CBT practices.

The current study is not without limitations. First, as most of respondents have been involved in the Tour Dure projects for less than four years, many of them are still at the training and educational stage of the projects, so more time may be needed to create bridging social capital. Therefore, a longitudinal 
study would need to investigate the change in innovativeness over time among project participants. Second, although we investigate the usefulness of a sustainable CBT model in Korea, more research is needed to test the effectiveness of this model both in Korea and globally. Third, this study focused on residents participating in Tour Dure projects without taking into account other stakeholders in CTB. Future studies could be expanded to embrace perspectives of other actors in Tour Dure communities and overall community well-being based on the interactions among other actors and even residents who are not participating in the project. In addition, it would be important to consider resident-tourist interactions in CBT integrating emotional solidarity as suggested by Dangi [74] and Joo et al. [4].

Author Contributions: Conceptualization, J.J., J.-J.C. and N.K.; methodology, J.J.; validation, J.J., J.-J.C. and N.K.; formal analysis, J.J.; investigation, J.J. and N.K.; data curation, J.J.; Writing-Original Draft preparation, J.J.; Writing-Review and Editing, J.-J.C. and N.K.; visualization, J.J. and N.K.; project administration, N.K.; funding acquisition, J.J., J.-J.C. and N.K.

Funding: This work was supported by the Ministry of Education of the Korea and the National Research Foundation of Korea (NRF-2017S1A5A2A03067485).

Conflicts of Interest: The authors declare no conflict of interest.

\section{Appendix A}

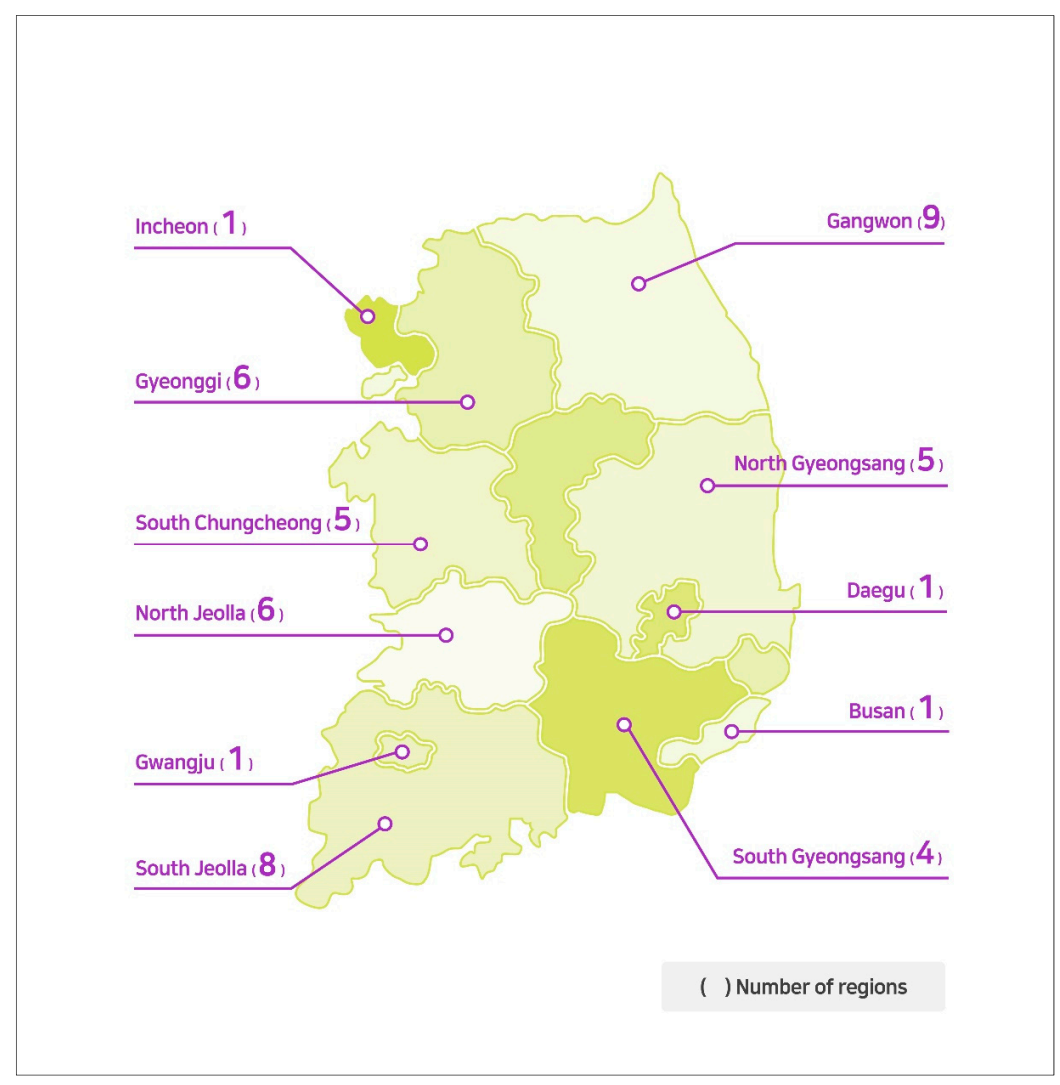

Figure A1. Tour Dure projects in 47 regions in South Korea.

\section{References}

1. Weaver, D. Community-based tourism as strategic dead-end. Tour. Recreat. Res. 2010, 35, 206-208. [CrossRef]

2. Dangi, T.B.; Jamal, T. An integrated approach to "sustainable community-based tourism". Sustainability 2016, 8, 475. [CrossRef]

3. Scheyvens, R. Ecotourism and the empowerment of local communities. Tour. Manag. 1999, 20, 245-249. [CrossRef] 
4. Joo, D.; Tasci, A.D.; Woosnam, K.M.; Maruyama, N.U.; Hollas, C.R.; Aleshinloye, K.D. Residents' attitude towards domestic tourists explained by contact, emotional solidarity and social distance. Tour. Manag. 2018, 64, 245-257. [CrossRef]

5. Park, S. Analysis of Saemaul Undong: A Korean rural development programme in the 1970s. Asia-Pac. Dev. J. 2009, 16, 113-140. [CrossRef]

6. Saul, J. Social Innovation, Inc.: 5 Strategies for Driving Business Growth through Social Change, 1st ed.; Jossey-Bass: San Francisco, CA, USA, 2010.

7. Battilana, J.; Casciaro, T. Change agents, networks, and institutions: A contingency theory of organizational change. Acad. Manag. J. 2012, 55, 381-398. [CrossRef]

8. Lee, M. An exploratory study on the crisis and restoration of the local communities. J. East Asian Soc. Thoughts 2016, 19, 87-115. (In Korean) [CrossRef]

9. OECD. How's Life? 2017: Measuring Well-Being; OECD Publishing: Paris, France, 2018.

10. Knight, B.; Suerdon, M.; Pharoah, C. Building a Civil Society; Charities Aid Foundation: London, UK, 1998.

11. Duncan, P.; Thomas, S. Neighbourhood Regeneration: Resourcing Community Involvement; The Policy Press and the Joseph Rowntree Foundation: Bristol, UK, 2000.

12. Coleman, J.S. Social Capital in the Creation of Human Capital. Am. J. Sociol. 1988, 94, S95-S120. [CrossRef]

13. Joo, J.; Eom, M.; Shin, M. Finding the missing link between corporate social responsibility and firm competitiveness through social capital: A business ecosystem perspective. Sustainability 2017, 9, 707. [CrossRef]

14. Joo, J.; Choi, J.; Kim, N. Social capital and innovation of tourism Doore communities from the perspective of business ecosystems. Proc. Conf. Int. J. Arts Sci. 2018, 11, 61-64.

15. Adler, P.S.; Kwon, S. Social capital: Prospects for a new concept. Acad. Manag. Rev. 2002, 27, 17-40. [CrossRef]

16. Nahapiet, J.; Ghoshal, S. Social capital, intellectual capital, and organizational advantage. Acad. Manag. Rev. 1998, 23, 242-266. [CrossRef]

17. Putnam, R.D. Bowling Alone: The Collapse and Revival of American Community; Simon \& Schuster: New York, NY, USA, 2000.

18. Ellison, N.B.; Steinfield, C.; Lampe, C. The benefits of Facebook "friends" Social capital and college students' use of online social network sites. J. Comput. Mediat. Commun. 2007, 12, 1143-1168. [CrossRef]

19. Ellison, N.B.; Vitak, J.; Gray, R.; Lampe, C. Cultivating social resources on social network sites: Facebook relationship maintenance behaviors and their role in social capital processes. J. Comput. Mediat. Commun. 2014, 19, 855-870. [CrossRef]

20. Burt, R.S. Structural Holes; Harvard University Press: Cambridge, MA, USA, 1992.

21. Coleman, J.S. Foundations of Social Theory; Harvard University Press: Cambridge, MA, USA, 1990.

22. Granovetter, M.S. The strength of weak ties. Am. J. Sociol. 1973, 78, 1360-1380. [CrossRef]

23. Granovetter, M. Getting a Job: A Study of Contacts and Careers; Harvard University Press: Cambridge, MA, USA, 1974.

24. Boström, M. A Missing Pillar? Challenges in theorizing and practicing social sustainability. Sustain. Sci. Pract. Policy 2012, 8, 3-14. [CrossRef]

25. Ribeiro, M.A.; Pinto, P.; Silva, J.A.; Woosnam, K.M. Examining the predictive validity of SUS-TAS with maximum parsimony in developing island countries. J. Sustain. Tour. 2018, 26, 379-398. [CrossRef]

26. Choi, H.C.; Murray, I. Resident attitudes toward sustainable community tourism. J. Sustain. Tour. 2010, 18, 575-594. [CrossRef]

27. Dempsey, N.; Bramley, G.; Power, S.; Brown, C. The social dimension of sustainable development: Defining urban social sustainability. Sustain. Dev. 2011, 19, 289-300. [CrossRef]

28. Källström, H.N.; Ljung, M. Social Sustainability and Collaborative Learning. AMBIO 2005, 34, 376-382. [CrossRef]

29. Maruyama, N.U.; Woosnam, K.M.; Boley, B.B. Residents' attitudes toward ethnic neighborhood tourism (ENT): Perspectives of ethnicity and empowerment. Tour. Geogr. 2017, 19, 265-286. [CrossRef]

30. Kim, S. The Improvement Plan of Tour Dure Project Implementation System; Culture \& Tourism Institution: Seoul, Korea, 2014. (In Korean) 
31. Kim, H.S.; Kim, C.W. A study on influencing factors and outcomes for cooperative governance of the Tourdoore: Perspective on moderating effects of Tourdoore producers' roles. Int. J. Tour. Hosp. Res. 2018, 32, 35-50. (In Korean)

32. Frank, K.A.; Zhao, Y.; Borman, K. Social Capital and the Diffusion of Innovations within Organizations: The case of computer technology in schools. Sociol. Educ. 2004, 77, 148-171. [CrossRef]

33. Easterling, D. The leadership role of community foundations in building social capital. Natl. Civic Rev. 2008, 97, 29-34. [CrossRef]

34. Kim, S.; Ryu, S. Social capital of the HR department, HR's change agent role, and HR effectiveness: Evidence from South Korean firms. Int. J. Hum. Resour. Manag. 2011, 22, 1638-1653. [CrossRef]

35. Monge, M.; Hartwich, F.; Halgin, D. How Change Agents and Social Capital Influence the Adoption of Innovations among Small Farmers: Evidence from Social Networks in Rural, Bolivia; IFPRI Discussion Paper 00761; International Food Policy Research Institute: Washington, DC, USA, 2008.

36. Casanueva, C.; Gallego, Á. Social capital and individual innovativeness in university research networks. Innovation 2010, 12, 105-117. [CrossRef]

37. Schienstock, G.; Hämäläinen, T. Transformation of the Finnish Innovation System: A Network Approach; Sitra Hels.: Helsinki, Finland, 2001; pp. 126-151.

38. Chang, S.C.; Chiang, C.Y.; Chu, C.Y.; Wang, Y.B. The Study of Social Capital, Organizational Learning, Innovativeness, Intellectual Capital, and Performance. J. Hum. Resour. Adult Learn. 2006, 2, 64-71.

39. Ahuja, G. Collaboration networks, structural holes and innovation: A Longitudinal Study. Adm. Sci. Q. 2000, 45, 425-455. [CrossRef]

40. Tura, T.; Harmaakorpi, V. Social capital in building regional innovative capability. Reg. Stud. 2005, 39, 1111-1125. [CrossRef]

41. Martínez-Pérez, Á.; García-Villaverde, P.M.; Elche, D. The mediating effect of ambidextrous knowledge strategy between social capital and innovation of cultural tourism clusters firms. Int. J. Contemp. Hosp. Manag. 2016, 28, 1484-1507. [CrossRef]

42. García-Villaverde, P.M.; Elche, D.; Martínez-Pérez, Á.; Ruiz-Ortega, M.J. Determinants of radical innovation in clustered firms of the hospitality and tourism industry. Int. J. Hosp. Manag. 2017, 61, 45-58. [CrossRef]

43. Kim, N.; Shim, C. Social capital, knowledge sharing and innovation of small- and medium-sized enterprises in a tourism cluster. Int. J. Contemp. Hosp. Manag. 2018, 30, 2417-2437. [CrossRef]

44. Ali, I. Personality traits, individual innovativeness and satisfaction with life. J. Innov. Knowl. 2019, 4, 38-46. [CrossRef]

45. Huhtala, H.; Parzefall, M.R. A review of employee well-being and innovativeness: An opportunity for a mutual benefit. Creat. Innov. Manag. 2007, 16, 299-306. [CrossRef]

46. Honkaniemi, L.; Lehtonen, M.H.; Hasu, M. Well-being and Innovativeness: Motivational Trigger Points for Mutual Enhancement. Eur. J. Train. Dev. 2015, 39, 393-408. [CrossRef]

47. Nimrod, G.; Kleiber, D.A. Reconsidering Change and Continuity in Later Life: Toward an Innovation Theory of Successful Aging. Int. J. Aging Hum. Dev. 2007, 65, 1-22. [CrossRef]

48. Nimrod, G. In Support of Innovation Theory: Innovation in Activity Patterns and Life Satisfaction among Recently Retired Individuals. Ageing Soc. 2008, 28, 831-846. [CrossRef]

49. Ikiz, F.E.; Asici, E. The Relationship between Individual Innovativeness and Psychological Well-Being: The Example of Turkish Counselor Trainees. Int. J. Prog. Educ. 2017, 13, 52-63.

50. Williams, D. On and Off the 'Net: Scales for Social Capital in an Online Era. J. Comput. Mediat. Commun. 2006, 11, 593-628. [CrossRef]

51. Agarwal, R.; Prasad, J. A conceptual and operational definition of personal innovativeness in the domain of information technology. Inf. Syst. Res. 1998, 9, 204-215. [CrossRef]

52. Tan, W.K.; Sie, M.S. The impact of personal innovativeness on product aesthetics and self-connection with brand: A case study of mobile phone users. Behav. Inf. Technol. 2015, 34, 316-325. [CrossRef]

53. Fornell, C.; Johnson, M.D.; Anderson, E.W.; Cha, J.; Bryant, B.E. The American customer satisfaction index: Nature, purpose, and findings [Electronic Version]. J. Mark. 1996, 60, 7-18. [CrossRef]

54. Hazleton, V.; Kennan, W. Social capital: Reconceptualizing the bottom line. Corp. Commun. Int. J. 2000, 5, 81-87. [CrossRef]

55. Tsai, W.; Ghoshal, S. Social capital and value creation: The role of interfirm networks. Acad. Manag. J. 1998, $41,464-476$. 
56. Eklinder-Frick, J.; Eriksson, L.T.; Hallén, L. Multidimensional social capital as a boost or a bar to innovativeness. Ind. Mark. Manag. 2014, 43, 460-472. [CrossRef]

57. Hsu, S.H. Developing an index for online customer satisfaction: Adaptation of American Customer Satisfaction Index. Expert Syst. Appl. 2008, 34, 3033-3042. [CrossRef]

58. Reinartz, W.; Haenlein, M.; Henseler, J. An empirical comparison of the efficacy of covariance-based and variance-based SEM. Int. J. Res. Mark. 2009, 26, 332-344. [CrossRef]

59. Ringle, C.M.; Wende, S.; Becker, J.-M. SmartPLS; SmartPLS GmbH: Boenningstedt, Germany, 2015.

60. Chin, W.W. The partial least squares approach for structural equation modeling. In Modern Methods for Business Research; Macoulides, G.A., Ed.; Lawrence Erlbaum Associates: Mahwah, NJ, USA, 1998; pp. $295-336$.

61. Podsakoff, P.M.; MacKenzie, S.B.; Lee, J.Y.; Podsakoff, N.P. Common Method Biases in Behavioral Research: A Critical Review of the Literature and Recommended Remedies. J. Appl. Psychol. 2003, 88, 879-903. [CrossRef]

62. Kock, N. Common method bias in PLS-SEM. Int. J. e-Collab. 2015, 11, 1-10. [CrossRef]

63. Hair, J.F.; Hult, G.T.M.; Ringle, C.; Sarstedt, M. A Primer on Partial Least Squares Structural Equation Modeling (PLS-SEM); SAGE Publications: Thousand Oaks, CA, USA, 2014.

64. Henseler, J.; Ringle, C.M.; Sarstedt, M. Using Partial Least Squares path modeling in international advertising research: Basic concepts and recent issues. In Handbook of Partial Least Squares: Concepts, Methods and Applications in Marketing and Related Fields; Okzaki, S., Ed.; Springer: Berlin, Germany, 2012; pp. 252-276.

65. Hair, J.F.; Ringle, C.M.; Sarstedt, M. Partial least squares: The better approach to structural equation modeling? Long Range Plan. 2012, 45, 312-319. [CrossRef]

66. Nunnally, J.C.; Bernstein, I.H. Psychometric Theory, 3rd ed.; McGraw-Hill: New York, NY, USA, 1994.

67. Fornell, C.; Larcker, D.F. Evaluating structural equation models with unobservable variables and measurement error. J. Mark. Res. 1981, 18, 39-50. [CrossRef]

68. Garson, G.D. Partial Least Squares: Regression \& Structural Equation Models. 2016. Available online: https://www.smartpls.com/resources/ebook_on_pls-sem.pdf (accessed on 2 February 2019).

69. Henseler, J.; Ringle, C.M.; Sarstedt, M. A new criterion for assessing discriminant validity in variance-based structural equation modeling. J. Acad. Mark. Sci. 2015, 43, 115-135. [CrossRef]

70. Gold, A.H.; Malhotra, A.; Segars, A.H. Knowledge management: An organizational capabilities perspective. J. Manag. Inf. Syst. 2001, 18, 185-214. [CrossRef]

71. Teo, T.S.H.; Srivastava, S.C.; Jiang, L. Trust and electronic government success: An empirical study. J. Manag. Inf. Syst. 2008, 25, 99-132. [CrossRef]

72. Kline, R.B. Principles and Practice of Structural Equation Modeling, 3rd ed.; The Guilford Press: New York, NY, USA, 2011.

73. Hu, L.; Bentler, P.M. Cutoff criteria for fit indexes in covariance structure analysis: Conventional criteria versus new alternatives. Struct. Equ. Model. 1999, 6, 1-55. [CrossRef]

74. Dangi, T. Exploring the intersections of emotional solidarity and ethic of care: An analysis of their synergistic contributions to sustainable community tourism development. Sustainability 2018, 10, 2713. [CrossRef]

75. Inaba, Y.; Wada, Y.; Ichida, Y.; Nishikawa, M. Which part of community social capital is related to life satisfaction and self-rated health? A multilevel analysis based on a nationwide mail survey in Japan. Soc. Sci. Med. 2015, 142, 169-182. [CrossRef]

76. Maass, R.; Kloeckner, C.A.; Lindstrøm, B.; Lillefjell, M. The Impact of Neighborhood Social Capital on Life Satisfaction and Self-Rated Health: A Possible Pathway for Health Promotion? Health Place 2016, 42, 120-128. [CrossRef]

77. Zou, T.; Su, Y.; Wang, Y. Examining relationships between social capital, emotion experience and life satisfaction for sustainable community. Sustainability 2018, 10, 2651. [CrossRef]

78. National Assembly Budget Office. Analysis of the Urban Regeneration New Deal. Available online: http://korea.nabo.go.kr/publi/publications.php?ptype=view\&idx=6595\&page=1\&code= publications\&category $=1042018$ (accessed on 5 August 2019).

(C) 2019 by the authors. Licensee MDPI, Basel, Switzerland. This article is an open access article distributed under the terms and conditions of the Creative Commons Attribution (CC BY) license (http://creativecommons.org/licenses/by/4.0/). 